\title{
STUDI KOLABORATIF DALAM PEMBANGUNAN PARIWISATA DI KAWASAN DERMAGA KERENG BANGKIRAI KOTA PALANGKA RAYA
}

\author{
Galadi
}

\begin{abstract}
This study raised collaborative issues in tourism development in the Kereng Bangkirai pier area of Palangka Raya City with the aim to determine the extent of collaboration carried out by the government, the private sector and the community in carrying out tourism development and to find out the inhibiting factors and supporters of collaboration in tourism development. The indicator in this study is to use the theory of Robert Agranoff and McGuire Michael (2003: 144-153) to view collaboration as activities that are horizontal and vertical. Then, the activity is analyzed through: (1) Communication (2) Value added (3) Deliberation.

This type of qualitative research with a descriptive approach. The research location is in the tourist area of the Kereng Bangkirai pier, Palangka Raya City. The informants in this study were the Head of Tourism, Staff of the Attractiveness Section, Chairperson of the tourism awareness group, Community and Community Leaders with Data Collection Techniques through (1) observation, (2) interviews, (3) documentation. While the data analysis technique uses the version of Miles and Huberman in Sugiyono (2012), namely (1) data reduction, (2) data presentation, and (3) conclusion drawing / verification.

As for the findings of the research, Collaboration conducted by the government, the private sector and the community in developing tourism uses: (a) Communication is the establishment of a forum and channel of communication that aims to provide mutual benefits including the formation of a tourism awareness group, also meetings that discuss tourism ; (b) Value added is the involvement of all elements in the tourism area of Kereng Bangkirai, both government, private and community; (c) Deliberation is a mutually beneficial cooperation between the government, the private sector and the community in the Kereng Bangkirai pier area, which results in positive changes in the form of mushrooming business premises in the form of stalls, shops, parking and provision of boat rental, water duck bikes, riverboats and photo booth. Supporting factors are: (a) Availability of infrastructure; (b) Budget availability; (c) Partnership; (d) Community participation. While the inhibiting factors (a) Limited human resources; (b) Budget limitations; (c) The condition of a pluralistic society.
\end{abstract}

\section{Keywords: Collaboration, Development and Tourism}

\section{PENDAHULUAN}

Sebagaimana diketahui bahwa sektor pariwisata di Indonesia masih menduduki peranan yang sangat penting dalam menunjang pembangunan nasional sekaligus merupakan salah satu faktor yang sangat strategis untuk meningkatkan pendapatan masyarakat dan devisa negara. Namun industri pariwisata harus peka terhadap kerusakan lingkungan seperti; pencemaran limbah, sampah yang 
bertumpuk, dan kerusakan pemandangan yang diakibatkan pembabatan hutan, serta sikap penduduk yang tidak ramah. Dengan kata lain aspek lingkungan lebih menekankan pada kelestarian ekosistem dan biodiversitas, pengelolaan limbah, penggunaan lahan, konservasi sumber daya air, proteksi atmosfer, dan minimalisasi kebisingan dan gangguan visual.

Selanjutnya dalam mengembangkan suatu objek pariwisata harus disertai dengan konsep pembangunan yang berkelanjutan. Pembangunan pariwisata berkelanjutan berguna untuk melestarikan kekayaan alam dan budaya yang dimiliki agar tetap dapat dinikmati generasi sekarang dan generasi yang akan datang. Menurut Piagam Pariwisata Berkelanjutan (1995) pembangunan pariwisata berkelanjutan adalah pembangunan yang didukung secara ekologis sekaligus layak secara ekonomi, juga adil secara etika dan sosial terhadap masyarakat. Artinya pembangunan berkelanjutan adalah upaya terpadu dan terorganisasi untuk mengembangkan kualitas hidup dengan cara mengatur penyediaan, pengembangan, pemanfaatan dan pemeliharaan sumber daya secara berkelanjutan, termasuk di dalamnya adalah lingkungan hidup atau dengan kata lain pembangunan berkelanjutan juga berorientasi pada kepedulian lingkungan hidup.

Salah satu unsur yang sangat menentukan perkembangan industri pariwisata adalah obyek wisata dan atraksi wisata. Daya tarik wisata alam adalah segala keunikan, keindahan dan keaslian keanekaragaman kekayaan alam hasil ciptaan Tuhan Yang Maha Esa. Daya tarik wisata alam dapat berupa sesuatu yang tetap dan dapat dinikmati keindahannya seperti hutan, sungai, danau, pantai, laut dan sebagainya. Selain itu adapula daya tarik wisata alam yang tidak tetap atau bergerak misalnya fenomena migrasi binatang, pasang surut lautan, bunga yang indah. Daya tarik wisata alam yang tidak tetap ini hanya dapat dinikmati pada waktu-waktu atau musim tertentu saja. Daya tarik wisata budaya adalah segala keunikan, keindahan dan keaslian (otentik) keanekaragaman kekayaan hasil kebudayaan setempat. Daya tarik wisata budaya dapat berupa hasil kebudayaan yang berwujud (tangible) seperti rumah adat, candi, benda-benda kesenian dan sebagainya. Selain itu, daya tarik wisata budaya dapat juga berupa hasil kebudayaan yang tidak berwujud fisik (intangible) seperti bahasa daerah, tari-tarian, upacara adat daur hidup, pertunjukan, sistem tata cara pertanian sederhana serta berbagai macam kearifan lokal lainnya.

Undang-Undang Republik Indonesia No. 10 Tahun 2009 tentang Kepariwisataan, menjelaskan beberapa pengertian istilah kepariwisataan, antara lain:

1. Wisata adalah suatu kegiatan perjalanan yang dilakukan oleh individu atau kelompok mengunjungi suatu tempat dan bertujuan untuk rekreasi, pengembangan pribadi, atau untuk mempelajari keunikan daya tarik suatu tempat wisata yang dikunjungi dalam waktu sementara.

2. Pariwisata adalah berbagai macam kegiatan wisata yang didukung oleh berbagai layanan fasilitas yang disediakan oleh masyarakat, pengusaha, pemerintah, dan pemerintah daerah.

3. Daerah tujuan wisata dapat disebut juga dengan destinasi pariwisata adalah kawasan geografis yang berada dalam satu atau lebih wilayah administrasi yang di dalamnya terdapat daya tarik wisata, fasilitas umum, fasilitas pariwisata, aksesbilitas, serta masyarakat yang saling terkait dan melengkapi terwujudnya kepariwisataan. 
Sementara itu Pemerintah Kota Palangka Raya melalui Dinas Kebudayaan dan Pariwisata memiliki visi yaitu :

"Dinas Kebudayaan dan Pariwisata Kota Palangka Raya sebagai bagian integral dari Pemerintah Kota Palangka Raya, yang memiliki tugas penyelenggaraan urusan pemerintahan dan tugas pembantuan lingkup kepariwisataan, pengembangan sumber daya pariwisata dan ekraf, pemasaran pariwisata serta kebudayaan. Sesuai Peraturan Daerah Kota Palangka Raya Nomor 11 Tahun 2016 tentang Pembentukan dan Susunan Perangkat Daerah Kota Palangka Raya dan Peraturan Walikota Palangka Raya Nomor 47 Tahun 2016 tentang Kedudukan, Susunan Organisasi, Tugas, Fungsi dan Tata Kerja Dinas Kota Palangka Raya, yang memiliki peran dan posisi strategis dalam kerangka pencapaian visi pembangunan jangka menengah Kota Palangka Raya yaitu: Tewujudnya Kota Palangka Raya sebagai Kota Pendidikan, Jasa dan Pariwisata yang Berwawasan Lingkungan berdasarkan Falsafah Budaya Betang sebagaimana tertuang dalam RPJMD Kota Palangka Raya Tahun 2013-2018 "senantiasa untuk melakukan upaya pengembangan destinasi wisata baik yang sudah ada maupun baru. Terjemahan dari visi tersebut adalah dengan dilakukannya secara simultan dan terus menerus aktifitas pengembangan dan peningkatan kawasan wisata yang memiliki nilai unik, khusus yang dapat menjadi perwujudan Kota Cantik Palangka Raya.

Diantara sejumlah tujuan wisata tersebut, Kota Cantik Palangka Raya menyimpan banyak sekali keindahan dan lokasi yang cocok untuk dijadikan tempat bersantai, dari sejumlah tujuan pariwisata yang dimiliki oleh Kota Palangka Raya, salah satunya adalah Danau/Pelabuhan Kereng Bangkirai yang berada di Desa Kereng Bangkirai, Kecamatan Sabangau, Kota Palangka Raya, Provinsi Kalimantan Tengah. Desa Kereng Bangkirai berdasar kepada Rencana Induk Pembangunan Kepariwisataan Kota Palangka Raya Tahun 2017-2028 Pasal 11 Ayat 4 Desa Kereng Bangkirai termasuk dalam KSP 4-KSP Kelampangan yang selanjutnya ditetapkan sebagai Kawasan Ekowisata (Rencana Induk Pembangunan Kepariwisataan Kota Palangka Raya 2017-2028). Adapun aktifitas kepariwisataan yang dilaksanakan oleh masyarakat telah terbentuk POKDARWIS (Kelompok Sadar Wisata) berdasar kepada Surat Keputusan Kepala Dinas Kebudayaan dan Pariwisata Kota Palangka Raya Nomor 09 Tahun 2018 tentang Pengukuhan Kelompok Sadar Wisata (POKDARWIS) Kelurahan Kereng Bangkirai Kecamatan Sebangau.

Dermaga Kereng Bangkirai dahulunya merupakan tempat bagi para atlet dayung untuk berlatih dan juga merupakan tempat dilaksanakannya kejuaraan nasional dayung di Kalimantan Tengah (Nining, Komunikasi Pribadi, 30 April 2018). Di Dermaga Kereng Bangkirai terdapat tribun yang sudah tua dan usang namun sekarang pemerintah Kota Palangka Raya telah merenovasi sebagian dari fasilitas yang ada di lokasi tersebut antara lain tribun dan ditambah dengan pondokpondok kecil yang dibuat disekitar pinggiran sungai Sebangau. Dengan penambahan pondok-pondok kecil dan renovasi yang dilakukan, sekarang Dermaga Kereng Bangkirai telah menjadi salah satu pusat wisata yang banyak diminati oleh wisatawan lokal maupun wisatawan mancanegara. Banyaknya wisatawan yang berkunjung dimanfaatkan oleh warga sekitar untuk membuka warung-warung kecil dan juga menyediakan berbagai wahana wisata yang dapat disewa oleh para wisatawan yang berkunjung. Wahana wisata yang ada di Dermaga Kereng Bangkirai yaitu sepeda bebek air, susur sungai, wisata ke batu ampar. Pelaksanaan 
aktifitas kepariwisataan dilaksanakan melalui kerjasama antara swasta, masyarakat dan pemerintah.

Kolaborasi tersebut terwujud melalui ketersediaan beberapa fasilitas penunjang seperti kapal susur sungai, perahu air, sepeda bebek air, warung makan, dan toko yang ada di sekitar wisata. Untuk itu penulis tertarik mengetahui sejauhmana kolaborasi yang dilaksanakan di Kawasan Wisata Dermaga Kereng Bangkirai Kota Palangka Raya.

\section{RUMUSAN MASALAH}

Rumusan masalah pada penelitian ini adalah :

1. Bagaimana kolaborasi yang dilakukan oleh pemerintah, swasta dan masyarakat dalam melakukan pembangunan pariwisata di kawasan dermaga Kereng Bangkirai Kota Palangka Raya?

2. Apa saja faktor pendukung dan penghambat kolaborasi yang dilaksanakan dalam pembangunan pariwisata di kawasan dermaga Kereng Bangkirai Kota Palangka Raya?

\section{TUJUAN PENELITIAN}

Tujuan dari dilakukannya penelitian ini adalah :

1. Mengetahui kolaborasi yang dilakukan oleh pemerintah, swasta dan masyarakat dalam melakukan pembangunan pariwisata di kawasan dermaga Kereng Bangkirai Kota Palangka Raya.

2. Mengetahui faktor penghambat dan pendukung kolaborasi yang dilaksanakan dalam pembangunan pariwisata di kawasan dermaga Kereng Bangkirai Kota Palangka Raya.

\section{KONSEP PEMBANGUNAN}

Konsep pembangunan biasanya melekat dalam konteks kajian suatu perubahan, pembangunan disini diartikan sebagai bentuk perubahan yang sifatnya direncanakan; setiap orang atau kelompok orang tentu akan mengharapkan perubahan yang mempunyai bentuk lebih baik bahkan sempurna dari keadaan yang sebelumnya; untuk mewujudkan harapan ini tentu harus memerlukan suatu perencanaan. Pembangunan secara berencana lebih dirasakan sebagai suatu usaha yang lebih rasional dan teratur bagi pembangunan masyarakat yang belum atau baru berkembang (Subandi: 2011:9-11)

Pembangunan pada hakekatnya adalah suatu proses transformasi masyarakat dari suatu keadaan pada keadaan yang lain yang makin mendekati tata masyarakat yang dicita-citakan; dalam proses transformasi itu ada dua hal yang perlu diperhatikan, yaitu keberlanjutan (continuity) dan perubahan (change), tarikan antara keduanya menimbulkan dinamika dalam perkembangan masyarakat.

Akan halnya kecenderungan konsep pembangunan yang dikembangkan di Indonesia. Menurut Wrihatnolo dan Dwijiwinoto (2007:65) mengemukakan adanya tahapan-tahapan sebagai berikut:

1. Strategi Pertumbuhan. Tahapan ini mempersoalkan tentang langkah-langkah besar (strategis) yang dipilih untuk meningkatkan pertumbuhan ekonomi yang tinggi. 
2. Pertumbuhan dan Distribusi. Tahap ini bukan semata-mata mempersoalkan tingginya pertumbuhan ekonomi, tetapi mempersoalkan pula tentang bagaimana distribusi atau pemerataan atas pertumbuhan ekonomi tersebut.

3. Teknologi tepat guna. Penguasaan teknologi tepat guna dinilai penting untuk diterapkan di negara berkembang, jenis teknologi ini bersifat padat karya sehingga dengan demikian dapat menyerap tenaga kerja yang sebanyakbanyaknya.

4. Kebutuhan dasar. Pertumbuhan ekonomi yang disertai dengan pemerataan hasilhasilnya dengan penerapan teknologi padat karya, dinilai masih belum mengurangi secara signifikan terjadinya kesenjangan ekonomi antara kelompok kaya dan miskin dan oleh karena itu dipandang perlu untuk pemenuhan kebutuhan dasar masyarakat.

5. Pembangunan berkelanjutan. Dampak dan pertumbuhan ekonomi jangka panjang sebagai akibat dari semakin tingginya tingkat konsumsi dan tabungan masyarakat, maka pembangunan akan terus berlanjut.

6. Pemberdayaan. Pemberdayaan pada dasarnya merupakan serangkaian aktifitas untuk memperkuat atau mengoptimalkan daya dari suatu kelompok sasaran, yaitu masyarakat yang kurang berdaya.

Menurut Rostow (1960:6-7) trasnformasi dari negara yang terbelakang menjadi negara maju dapat dijelaskan melalui suatu urutan tingkatan atau tahap pembangunan yang dilalui oleh semua negara. Rostow (1960) mengemukakan lima tahap yang dilalui oleh suatu negara dalam proses pembangunannya yaitu:

1. Masyarakat tradisional adalah masyarakat yang belum mengetahui teknologi modern, tetapi masih mengandalkan tenaga fisik. Sektor utamanya masih berbasis pertanian, perikanan, kehutanan dan perternakan.

2. Persiapan menuju tingkat landas merupakan masyarakat yang mulai banyak menggunakan ilmu dan teknologi modern untuk menuju negara industri.

3. Tinggal landas merupakan pertumbuhan ekonomi meningkat dengan prioritas pembangunan di sektor industri

4. Masyarakat dewasa merupakan masyarakat menggunakan teknologi modern untuk melakukan semua aktivitas ekonominya.

5. Masa tingginya konsumsi masyarakat merupakan masyarakat memiliki tingkat konsumsi yang tinggi untuk produksi barang dan jasa.

\section{PENGERTIAN PARIWISATA}

Secara Etimologi, kata pariwisata berasal dari bahasa Sansekerta yang terdiri atas dua suku kata, yaitu pari dan wisatawan. (Musanef, 1996:8). Pari berarti seluruh, semua dan penuh. Wisata berarti perjalanan. Dengan demikian pariwisata dapat diartikan sebagai perjalanan penuh, yaitu berangkat dari suatu tempat, menuju dan singgah, di suatu di beberapa tempat, dan kembali ke tempat asal semula.

Menurut Soekadijo (Soekadijo, 1997:2) pariwisata adalah segala kegiatan dalam masyarakat yang berhubungan dengan wisatawan. Semua kegiatan pembangunan hotel, pemugaran cagar budaya, pembuatan pusat rekreasi, penyelenggaraan pekan pariwisata, penyediaan angkutan dan sebagainya semua itu dapat disebut kegiatan pariwisata sepanjang dengan kegiatan-kegiatan itu semua dapat diharapkan para wisatawan akan datang.

Sementara itu A. J. Burkart dan S. Medlik (1981:46) dalam Soekadijo, (1997: 3) mengungkapkan bahwa: “Tourism: past, present and future”, berbunyi 
"pariwisata berarti perpindahan orang untuk sementara (dan) dalam jangka waktu pendek ke tujuan-tujuan di luar tempat dimana mereka biasanya hidup dan bekerja, dan kegiatan-kegiatan mereka selama tinggal di tempat-tempat tujuan itu.

Menurut Oka A. Yoeti (1990:109) mendefinisikan pariwisata sebagai suatu perjalanan yang dilakukan untuk sementara waktu, yang diselenggarakan dari suatu tempat ke tempat lain, dengan maksud bukan untuk berusaha (business) atau mencari nafkah ditempat yang dikunjungi, tetapi semata-mata untuk menikmati perjalanan tersebut guna bertamasya dan rekreasi atau untuk memenuhi keinginan yang beraneka ragam.

Sedangkan yang disebut wisatawan adalah orang yang mengadakan perjalanan dari tempat kediamannya tanpa menetap ditempat yang didatanginya, atau hanya untuk sementara waktu tinggal ditempat yang didatanginya. Nyoman S. Pendit (1999: 42-48) memperinci penggolongan pariwisata menjadi beberapa jenis yaitu :

1. Wisata Budaya

2. Wisata Kesehatan

3. Wisata Olah Raga

4. Wisata Komersial

5. Wisata Industri

6. Wisata Politik

7. Wisata Konvensi

8. Wisata Sosial

9. Wisata Pertanian

10. Wisata Maritim (Marina) atau Bahari

11. Wisata Cagar Alam

12. Wisata Buru

13. Wisata Pilgrim

14. Wisata Bulan Madu

Menurut James J. Spillane (1994: 28-30) terdapat empat pendekatan didalam pariwisata yang muncul secara kronologis yakni :

1. Pendekatan Advocacy

2. Pendekatan Cautionary

3. Pendekatan Adaptancy

4. Pendekatan Developmental

Menurut Oka A. Yoeti (1990: 111-113), letak geografis, dimana kegiatan pariwisata berkembang meliputi :

1. Pariwisata Lokal (Local Tourism)

2. Pariwisata Regional (Regional Tourism)

3. Pariwisata Nasional

4. Regional-Internasional Tourism

5. International Tourism

\section{KONSEP PENGEMBANGAN PARIWISATA}

Perencanaan dan pengembangan pariwisata merupakan suatu proses yang dinamis dan berkelanjutan menuju ketataran nilai yang lebih tinggi dengan cara melakukan penyesuaian dan koreksi berdasar pada hasil monitoring dan evaluasi serta umpan balik implementasi rencana sebelumnya yang merupakan dasar kebijaksanaan dan merupakan misi yang harus dikembangkan. Perencanaan dan 
pengembangan pariwisata bukanlah system yang berdiri sendiri, melainkan terkait erat dengan sistem perencanaan pembangunan yang lain secara inter sektoral dan inter regional.

Menurut Kamus Umum Bahasa Indonesia, definisi pengembangan adalah hal, cara atau hasil kerja mengembangkan. Sedangkan mengembangkan berarti membuka, memajukan, menjadikan maju dan bertambah baik. Pengembangan pariwisata dapat diartikan usaha atau cara untuk membuat jadi lebih baik segala sesuatu yang dapat dilihat dan dinikmati oleh manusia sehingga semakin menimbulkan perasaan senang dengan demikian akan menarik wisatawan untuk berkunjung.

Menurut Suwantoro (1997:33) pola kebijakan pengembangan obyek wisata yang meliputi :

1. Prioritas pengembangan obyek

2. Pengembangan pusat-pusat penyebaran kegiatan wisatawan

3. Memungkinkan kegiatan penunjang pengembangan obyek wisata

Dalam pengembangan obyek wisata ini, perlu diperhatikan tentang prasarana pariwisata, sarana wisata, infrastruktur pariwisata dan masyarakat sekitar obyek wisata tersebut. Menurut James J. Spillane (1994:63-72) suatu tujuan pariwisata, harus meliputi lima unsur yang penting agar wisatawan dapat merasa puas dalam menikmati wisatanya yaitu meliputi:

1. Atraksi

2. Fasilitas

3. Infrastruktur

4. Transportasi

5. Hospitality/keramah-tamahan

\section{KOLABORASI}

Kolaborasi merupakan kata serapan yang berasal dari bahasa Latin yakni collaborare yang artinya "bekerja bersama" Merriam-Webster (1828). Dalam kamus Heritage Amerika (2000), kolaborasi diartikan sebagai kegiatan bekerjasama khususnya dalam usaha penyatuan pemikiran. Hal itu senada dengan pendapat Wood \& Gray (1991: 5) yang mengemukakan bahwa: "Collaboration as a process through which parties who see different aspects of a problem can constructively explore their differences and search for solutions that go beyond their own limited vision of what is possible"

Kolaborasi merupakan suatu proses dimana pihak-pihak yang terlibat melihat suatu permasalahan dari persepektif atau aspek yang berbeda dapat secara konstruktif mempertemukan perbedaan dan mencari solusi lebih jauh dari pandangan mereka akan apa yang mungkin .

Pendapat lain dikemukakan oleh Chrislip dan Larson (1994:5) dalam Wood \& Gray, (1991: 139-162) yang mendefinisikan kolaborasi sebagai berikut: "Collaboration is a mutually beneficial relationship between two or more parties who work toward common goals by sharing responsibility, authority, and accountability for achieving results"

Berdasarkan kutipan di atas, kolaborasi dapat diartikan sebagai hubungan yang saling menguntungkan antara dua pihak atau lebih yang bekerjasama dalam berbagi tanggung jawab, wewenang, dan akuntabilitas untuk mencapai hasil dan tujuan bersama. 
Menurut buku yang diterbitkan WWF (World Wildlife Funding) pada tahun 2010 yang berjudul Stakeholder Collaboration "Building Bridges for Conservation”, kolaborasi merupakan kerjasama yang mengandalkan kepercayaan, inklusi, dan keterlibatan yang konstruktif untuk mencapai tujuan bersama.

Thomson dan Perry (2006: 23) mengembangkan definisi kolaborasi sebagai proses dimana aktor yang memiliki wewenang otonom berinteraksi melalui negoisasi formal dan informal, bersama-sama menciptakan aturan dan struktur yang mengatur hubungan dan cara bertindak atau memberikan keputusan atas isu-isu yang membawa mereka dalam keharusan kebersamaan. Hal ini merupakan interaksi yang saling menguntungkan.

Definisi lain pada sektor administrasi publik dikemukakan oleh Ansell dan Gash (2007: 544) yang mengembangkan kerangka konsep kolaborasi dengan pendekatan berbasis sistem yang kemudian menemukan konsep "collaboration governance" (kolaborasi pemerintahan) yang didefinisikan sebagai berikut: " $a$ governing arrangement where one or more public agencies directly engage nonstate stakeholders in a collective decision-making process that is formal, consesusorientated, and deliberative and that aims to make or implement public or manage public programs or assets”

Kolaborasi pemerintahan berdasarkan kutipan di atas dapat diartikan sebagai susunan pemerintahan dimana satu atau lebih lembaga publik secara langsung terlibat dengan stakeholder non-pemerintah dalam proses pengambilan keputusan kolektif yang formal, berorientasi konsesus dan deliberatif, yang bertujuan untuk membuat atau mengimplementasikan kebijakan publik atau mengelola kebijakan program atau mengelola suatu aset.

Emerson et, al. (2012) dalam Morris et, al., (2015: 19) memperbaiki dan mengembangkan pendapat Ansell dan Gash dengan menghilangkan penekanan pada pemerintah sebagai penggerak kolaborasi. Emerson et, al. menggambarkan "rezim pemerintahan kolaboratif (collaborative governance regime)" sebagai: "Processes and structures of public policy decision making and management that engage people constructively across the boundaries of public agencies, levels of government, and/or the public, privat and civic spheres in order to carry out a public purpose that could not otherwise be accomplished"

Proses dan struktur pengambilan keputusan kebijakan publik dan manajemen yang melibatkan orang-orang secara konstruktif melintasi batas-batas lembaga publik, tingkat pemerintahan, dan/atau sektor umum, pribadi dan sipil untuk mewujudkan tujuan umum yang akan dicapai.

Konsep rezim pemerintahan kolaboratif ini diperkuat oleh proses kolaborasi yang berulang-ulang dimana prinsip keterlibatan (komunikasi), berbagi motivasi (kepercayaan, komitmen, dan mutualitas), dan kapasitas untuk tindakan kolektif (administrasi) saling memperkuat satu sama lain dalam sebuah umpan balik yang positif untuk meningkatkan kualitas dan dinamika kolaborasi.

Menurut Carpenter (1990:123) dalam buku yang diterbitkan oleh WWF, kolaborasi memiliki 7 (tujuh) karakteristik, yaitu sebagai berikut:

1. Partisipasi bersifat inklusif (tidak dibatasi) dan tidak hierarki

2. Partisipasi bertanggung jawab dalam memastikan pencapaian kesuksesan

3. Adanya tujuan yang jelas dan pendefinisian masalah

4. Partisipan saling membagi pengetahuannya satu sama lain (educating each other) 
5. Adanya identifikasi dan pengujian terhadap berbagai pilihan

6. Partisipan berbagi peran dan tanggung jawab dalam pengimplementasian solusi

7. Partisipan selalu mengetahui perkembangan yang ada

Berdasarkan berbagai penjelasan tentang pengertian kolaborasi di atas, kolaborasi dalam penelitian ini adalah kerjasama antar stakeholders yang bersifat saling bergantung untuk mencapai keputusan kolektif dalam mencapai tujuan bersama dimana setiap aktor yang berkolaborasi memiliki hubungan yang lebih dekat, komunikasi yang intensif, serta seringkali mengaburkan batas-batas organisasi. Untuk lebih memahami kolaborasi dalam penelitian ini, berikut akan dijelaskan dimensi-dimensi dan komponen-komponen yang menyusun sebuah kolaborasi.

\section{Komponen-Komponen Kolaborasi}

Dalam sebuah kolaborasi terdapat komponen-komponen yang menjadi kunci keberhasilan kolaborasi itu sendiri. Komponen-komponen tersebut saling melengkapi satu sama lain, sehingga kolaborasi akan berhasil apabila memenuhi semua komponen.

Grey (1989:43-46) berpendapat bahwa kolaborasi melibatkan beberapa komponen yaitu (1) saling ketergantungan, (2) penyatuan pemikiran secara konstruktif untuk mencapai solusi, (3) joint ownership of decisions (keputusan bersama semua aktor), (4) tanggung jawab bersama.

Pendapat lain dikemukakan oleh Roberts dan Bradley (1991:83) dalam Thomson dan Perry (2006: 20-32) berpendapat bahwa komponen utama kolaborasi adalah transmutational puspose (penyatuan tujuan), keanggotaan yang tetap dan sukarela, organisasi, proses interaktif, dan properti sementara.

Menurut Healey (1996: 208), kolaborasi memerlukan strategi melalui tiga modal, yakni modal sosial yang terdiri dari kepercayaan, komunikasi, dan kemauan bertukar pikiran; modal intelektual yang terdiri dari pemahaman; dan modal politik yang terdiri dari perjanjian dan proyek formal maupun informal.

Berikut ini akan dijelaskan tiga komponen kolaborasi menurut Robert Agranoff dan Michael McGuire (2003), lima dimensi kolaborasi menurut Thomson dan Perry (2006), lima komponen kolaborasi menurut Ansell dan Gash (2007), dan lima komponen menurut Roberts et al. (2016).

\section{Robert Agranoff dan Michael McGuire}

Agranoff dan McGuire (2003: 144-153) memandang kolaborasi sebagai aktivitas-aktivitas yang bersifat horizontal dan vertikal. Kemudian, aktivitas tersebut dianalisis melalui komponen-komponen sebagai berikut:

\section{a. Komunikasi}

Komunikasi yang intensif sangatlah penting dalam kolaborasi. Kolaborasi dapat dilakukan secara langsung dan tidak langsung. Komunikasi yang dilakukan secara tidak langsung dapat melalui perantara teknologi. Komunikasi melalui perantara akan lebih efektif diterapkan pada kolaborasi yang terdapat konflik antar aktor.

\section{b. Nilai tambah}

Nilai yang dimaksud disini adalah nilai publik, yakni yang dihasilkan dari efisiensi, demokrasi dalam institusi/organisasi, dan proses kolaborasi. Permasalahan dalam menciptakan nilai publik adalah adanya tingkat kepentingan, urgensi, ruang lingkup permasalahan yang meranah lintas- 
sektoral, sehingga menyadarkan bahwa pemerintah sendiri tidak mampu menciptakan bagian penting dari nilai publik itu sendiri (Muqorrobin, 2016: 41), sehingga diperlukan kolaborasi dengan aktor non-pemerintah.

\section{c. Deliberasi}

Deliberasi merupakan kelebihan dari kolaborasi yang membentuk pembelajaran saling menguntungkan (mutual learning), pembangunan komunitas (building communities), dan pemanfaatan proses interaktif (employing interactive).

\section{Ann Marie Thomson dan James L. Perry}

Dimensi merupakan himpunan yang terdiri dari komponen-komponen tertentu yang menyusun sebuah konsep dan memiliki hubungan ketergantungan antar komponen (Mustafa, 2009:22).

Thomson dan Perry dalam tulisannya yang berjudul "Collaboration Processes: Inside The Black Box" berpendapat bahwa terdapat 5 (lima) kunci dimensi kolaborasi (Thomas dan Perry, 2006: 24-28), yaitu sebagai berikut:

\section{a. Dimensi Tata Pemerintahan (The Process of Collaborative Governing: The Governance Dimension)}

Dimensi pemerintahan berkaitan dengan pengambilan keputusan bersama (joint decision making), pengaturan pembagian daya, dan pemecahan masalah. Pada dimensi pemerintahan terdapat hal-hal yang harus diperhatikan, yakni sebagai berikut: (1) struktur hierarki dan otoritas tidak mendominasi; (2) kesadaran bahwa pihak yang berkolaborasi tidak hanya secara langsung bertanggung jawab untuk mencapai kesepakatan tetapi juga harus memaksakan keputusan pada diri mereka sendiri; (3) ketersediaan untuk menerima bahwa semua pihak yang berkolaborasi memiliki kepentingan yang sah sehingga hasilnya mencerminkan konsesus kelompok, bukan kekuatan koalisi atau kekuatan politik; dan (4) pemahaman bahwa pemerintahan harus menekankan keterbukaan informasi, menghormati pendapat orang lain, dan melalui negoisasi yang panjang dalam mencapai kesepakatan.

b. Dimensi Administrasi (The Process of Collaborative: The Administration Dimension)

Dimensi administrasi dalam kolaborasi sangat penting dalam keberlangsungan hubungan pihak-pihak yang berkolaborasi. Struktur administrasi dalam kolaborasi memiliki posisi sentral untuk koordinasi komunikasi, pengorganisasian dan penyebaran informasi, serta mengupayakan pihak-pihak yang berkolaborasi untuk bersama-sama mengatur hubungan mereka, dimana Freitag dan Winkler menyebutnya sebagai "sosial koordinasi”.

Indikator dalam dimensi administrasi adalah kejelasan peran dan tanggung jawab setiap aktor, pertemuan kerja sama yang efektif, kejelasan tujuan, tugas-tugas terkoordinasi dengan baik, terdapat saluran komunikasi yang formal, dan pemantauan dalam pelaksanaan kolaborasi (Thomson, Perry, and Miller, 2008: 104).

c. Dimensi Otonomi (The Process of Reconciling Individual and Collective Interest: The Autonomy Dimension) 
Dimensi otonomi memiliki hubungan yang kontras antara kontrol bersama dan kontrol individu (Wood dan Grey, 1991:46). Dalam sebuah kolaborasi, aktor yang terlibat melindungi identitas mereka dengan mempertahakan kontrol individu. Di sisi lain, kontrol bersama melibatkan ketersediaan mitra untuk berbagi informasi, bukan hanya tentang operasi organisasi mereka sendiri, tetapi juga tentang apa yang mereka bisa dan tidak bisa dalam berkolaborasi.

Dimensi otonomi mencoba untuk menangkap ketegangan yang implisit antara kepentingan aktor dan kepentingan bersama. Indikator dimensi otonomi ini berkaitan dengan sejauh mana aktor melihat kolaborasi sebagai penghalang misi organisasi, kepercayaan bahwa keuntungan mereka dipengaruhi oleh kolaborasi, dan kesadaran aktor untuk berusaha memenuhi harapan organisasi dan harapan aktor lain dalam kolaborasi.

d. Dimensi Mutualitas (The Process of Forging Mutually Benefical Relationship: The Mutuality Dimension)

Dimensi mutualisme berakar pada saling ketergantungan. Sebuah organisasi harus mengalami saling ketergantungan baik dalam kesamaan kepentingan maupun perbedaan kepentingan, yang kemudian disebut Powell (1990:694) sebagai “complementarities”. Komplementaritas menjelaskan situasi dimana suatu organisasi mengorbankan haknya untuk mendapatkan daya dari organisasi lain demi mencapai kepentingan mereka sendiri. Dalam kolaborasi, adanya saling ketergantungan merupakan kunci yang penting agar hubungan antar aktor terus terjalin dengan baik.

e. Proses Membangun Norma Sosial: Kepercayaan dan Dimensi Timbal Balik (The Process of Building Social Capital Norms: The Trust and Reciprocity Dimension)

Dalam kolaborasi, aktor individu akan menunjukkan kesediaan untuk berinteraksi dalam kolaborasi jika aktor yang lain juga menunjukkan kesediaan yang sama. Hubungan timbal balik tersebut akan membentuk kepercayaan antar pihak-pihak yang berkolaborasi jika dilakukan secara berulang-ulang.

Adanya kepercayaan antar pihak-pihak yang berkolaborasi memberikan manfaat trehadap kelangsungan kolaborasi, yakni: (1) membuat itikad baik, pihak-pihak yang berkolaborasi akan berperilaku sesuai komitmen eksplisit dan implisit; (2) jujur dalam negoisasi apapun; (3) pihakpihak yang berkolaborasi tidak akan mengambil keuntungan yang lebih meskipun terdapat kesempatan (Cummings dan Bromiley, 1993: 303).

\section{Chris Ansell dan Alison Gash}

Ansell dan Gash berpendapat bahwa dalam kolaborasi terdapat komponen-komponen yang membentuk siklus dan mempengaruhi satu sama lain (Ansell dan Gash, 2007: 558-561). Komponen-komponen tersebut akan dijelaskan sebagai berikut:

\section{a. Dialog antar-muka (face to face dialogue)}

Dialog antar-muka sebagai bentuk komunikasi menjadi hal yang penting dalam kolaborasi, karena adanya proses pembentukan konsesus. Komunikasi langsung (face to face) merupakan upaya untuk mengurangi streotipe (yaitu persepsi aktor yang memandang adanya sisi buruk aktor lain) 
dan meningkatkan rasa hormat antar aktor. Dengan adanya komunikasi langsung, para aktor yang terlibat dalam kolaborasi menjadi lebih objektif dalam berinteraksi.

\section{b. Membangun kepercayaan (trust building)}

Membangun kepercayaan merupakan syarat yang diperlukan untuk membangun kolaborasi yang solid. Membangun kepercayaan memerlukan waktu yang tidak singkat, hal ini karena dalam kolaborasi diperlukan komunikasi yang intensif (terus menerus) dan penyesuaian terhadap kondisi saat ini dari munculnya kembali konflik masa lalu (prehistory antagonism). Ansell dan Gash (2007: 559) mengemukakan argumentasinya sebagai berikut: "If the prehistory is highly antagonistic, then policy makers or stakeholders should budget time for effective remedial trust building. If they cannot justify the necessary time and cost, then they should not embark on a collaboration strategy"

Pembuat kebijakan atau stakeholders harus mengalokasikan waktu untuk melakukan remedial pembangunan kepercayaan secara efektif. Apabila tidak, maka kolaborasi tidak seharusnya dilakukan.

\section{c. Komitmen pada proses kolaborasi (commitment to the process)}

Komitmen merupakan komponen yang sangat penting dalam proses kolaborasi. Komitmen berkaitan erat dengan motivasi asli para aktor dalam kolaborasi. Komitmen dipengaruhi oleh beberapa faktor, yakni (1) mutual recognition yaitu berkaitan dengan pengakuan bersama; (2) joint appreciation yakni apresiasi bersama para aktor; (3) kepercayaan antar aktor; (4) ownership the process (rasa memiliki pada proses), hal ini berkaitan dengan pengaruh setiap aktor dalam pengambilan keputusan namun memiliki dilema, karena adanya kompleksitas dalam kolaborasi; (5) interdependence yakni saling ketergantungan antar aktor. Perbedaan kapasitas yang dimiliki para aktor memunculkan rasa ketergantungan yang dapat menumbuhkan dan memperkuat komitmen.

\section{d. Pemahaman bersama (shared understanding)}

Pemahaman bersama merupakan hal yang penting dalam mencapai tujuan bersama. Pemahaman bersama dapat diartikan sebagai common misision (misi umum), common purpose (tujuan umum), common objectives (obyektivitas umum), dan shared vision (visi bersama). Pemahaman yang dimaksud adalah penyatuan pemikiran dan persamaan tujuan, sehingga meminimalisir terjadinya kesalahpahaman antar aktor.

\section{e. Dampak sementara (intermediate outcomes)}

Dampak sementara terjadi selama proses kolaborasi, oleh karena itu ada kata "sementara" di dalamnya. Dampak sementara menghasilkan feedbacks. Umpan balik yang diharapkan adalah umpan balik yang positif, yang disebut "small-wins" (kemenangan kecil) atau Roberts dan Bradley (1991:83-91) menyebutnya sebagai temporal property. Kemenangan kecil ini akan meningkatkan harapan masing-masing aktor dalam kolaborasi sehingga dapat meningkatkan kepercayaan dan komitmen.

\section{Debbie Roberts, Rene van Wyk, dan Nalesh Dhanpat}

Dalam temuan penelitian yang telah dilakukan oleh Roberts et al. (2016: 4-6) yang berjudul "Exploring Practices for Effective Collaboration” terdapat lima kunci kolaborasi, yakni sebagai berikut: 


\section{a. Tujuan Umum (common purpose)}

Visi bersama adalah faktor kunci kolaborasi yang akan membawa para aktor tetap bersama-sama mencapai tujuan tersebut.

\section{b. Mutualitas (mutuality)}

Mutualitas terjadi ketika masing- masing pihak memberikan kontribusi sumber daya sehingga pihak lain memperoleh manfaat, misalnya saling bertukar informasi. Kesamaan misi, budaya, dan komitmen terhadap tujuan kolaborasi membantu memfasilitasi pertukaran sumber daya.

\section{c. Lingkungan yang memungkinkan (enabling environment)}

Lingkungan kolaboratif terdiri dari lingkungan kerja dan gaya kepemimpinan pemimpin kolaborasi. Lingkungan kerja dan gaya kepimpinan memiliki pengaruh yang kuat terhadap kinerja para aktor dalam menjalankan kolaborasi. Kepemimpinan memiliki peran penting dalam menciptakan dan mempertahankan sebuah lingkungan kolaboratif dengan cara menghubungkan keahlian dan pengetahuan para aktor.

\section{d. Kepercayaan (trust)}

Kepercayaan adalah salah satu faktor yang paling mendasari keberhasilan kolaborasi. Kepercayaan didasarkan pada keyakinan bahwa para aktor akan jujur dalam perjanjian dan mematuhi komitmen mereka dan tidak mengeksploitasi pihak lain.

Adanya kontrol formal yang berlebihan dapat mengurangi kepercayaan antar aktor karena kontrol dianggap sebagai tanda ketidakpercayaan mengenai kemampuan dan karakter para aktor.

\section{e. Karakteristik pribadi tertentu (spesific personal characteristics)}

Dalam sebuah kolaborasi, para aktor harus terbuka dan mampu memahami motif dan kepentingan aktor lain. Pemahaman karakteristik aktor yang berkolaborasi dapat menumbuhkan kompromi sebagai konsekuensi dari pembuatan keputusan bersama dimana terdapat kepentingan aktor yang tidak terjawab dalam keputusan tersebut.

\section{JENIS PENELITIAN}

Penelitian ini menggunakan metode penelitian kualitatif dengan pendekatan deskriptif. Menurut Hadari Nawawi (2003:165), mendefinisikan penelitian deskriptif adalah sebagai prosedur pemecahan masalah yang diselidiki dengan menggambarkan atau melukiskan keadaan subjek/ objek penelitian (seseorang, lembaga, masyarakat, dan lain-lain) pada saat sekarang berdasarkan fakta-fakta yang tampak sebagaimana adanya. Penelitian deskriptif melakukan analisa hanya pada sampai taraf deskripsi, yaitu menganalisis dan menyajikan fakta secara sistematis, sehingga dapat dipahami dan disimpulkan. Sedangkan Menurut Eddy dan Helmuth (2013:2) mengemukakan penelitian kualitatif adalah salah satu metode penelitian yang bertujuan untuk mendapatkan pemahaman tentang kenyataan melalui proses berpikir induktif. Melalui penelitian kualitatif peneliti dapat meneliti subjek, merasakan apa yang mereka alami dalam kehidupan sehari-hari dan dapat memahami pemahaman mereka, sekaligus dapat memaknai tindakan mereka.

\section{LOKASI PENELITIAN}

Lokasi penelitian ini penulis lakukan di Kawasan Wisata Dermaga Kereng Bangkirai Kota Palangka Raya. Alasan dijadikannya lokasi tersebut sebagai lokasi 
penelitian adalah karena besarnya animo masyarakat untuk melakukan kegiatan wisata di Kawasan Wisata Dermaga Kereng Bangkirai Kota Palangka Raya namun belum diketahuinya secara menyeluruh mengenai konsep dan upaya pengembangan Kawasan Wisata yang dilaksanakan oleh berbagai pihak yang sedianya bisa menjadi andalan wisata di Kota Palangka Raya.

\section{SUMBER DATA}

Sumber data pada penelitian ini di dapat dari tempat yang dijadikan objek sumber informasi. Adapun sumber datanya adalah sebagai berikut :

1. Data primer yaitu data utama yang dijadikan landasan penulis dalam penelitian. Data primer diperoleh dari narasumber dengan melakukan wawancara dan pengamatan langsung. Adapun narasumber yang dimaksud ialah sebagai berikut

a. Pihak Pemerintah : Dinas Kebudayaan dan Pariwisata Kota Palangka Raya

b. Pihak Swasta : Penyedia Jasa Di Seputar Wilayah Danau Kereng Bangkirai, Biro Perjalanan Wisata, dan Pemandu Wisata

c. Pihak Masyarakat : Kelompok Sadar Wisata (POKDARWIS), Tokohtokoh Masyarakat dan Pengunjung Objek Wisata.

2. Sekunder yaitu data pendukung yang digunakan oleh penulis sebagai pelengkap untuk menelaah segi-segi subjektif dari penelitian yang dianalisis. Data sekunder meliputi dokumen-dokumen dan arsip yang dimiliki oleh para narasumber.

\section{TEKNIK PENGUMPULAN DATA}

Teknik pengumpulan data dalam penelitian ini adalah:

\section{Observasi}

Observasi adalah dasar semua ilmu pengetahuan. Para ilmuan hanya bisa bekerja berdasarkan data, yaitu fakta mengenai dunia kenyataan yang diperoleh melalui observasi dalam melaksanakan observasi, peneliti bukan hanya sekedar mencatat, tetapi juga harus menggunakan alat bantu berupa handphone atau kamera digital untuk memperoleh data di lapangan. Hasil dari pengamatan tersebut dapat dilakukan dengan pencatatan berupa dokumentasi.

\section{Wawancara}

Wawancara adalah percakapan dengan maksud tertentu, yang dilakukan oleh dua pihak atau lebih, yaitu pewawancara (interviewer) yang mengajukan pertanyaan dan yang diwawancarai (Interviewee atau informant) yang memberikan jawaban atas pertanyaan itu. (Eddy dan Helmuth, 2003:109). Wawancara merupakan sebuah proses komunikasi yang dilakukan secara langsung. Kunci utama dalam wawancara yang memberikan informasi yang dibutuhkan pewawancara dituntun untuk menjalin keakraban dengan informan melalui teknik dan cara-cara tertentu. Kemudian waktu yang tepat juga harus dipikirkan situasinya.

Adapun jenis wawancara yang dilakukan dalam penelitian ini adalah menggunakan wawancara semi terstruktur, Dengan alasan wawancara semi terstruktur lebih tepat dilakukan dalam penelitian kualitatif daripada penelitian lainnya. Ciri-ciri dari wawancara semi terstruktur adalah pertanyaan terbuka namun ada batasan tema dan alur pembicaraan, kecepatan wawancara dapat 
diprediksi, fleksibel tetapi terkontrol, ada pedoman wawancara yang dijadikan patokan dalam alur, urutan dan penggunaan kata, dan tujuan wawancara adalah untuk memahami suatu fenomena. (Haris Herdiansyah, 2011:121)

Data yang dicari menggunakan teknik ini adalah data yang berkenaan dengan Kolaboratif Dalam Pembangunan Pariwisata Di Kawasan Dermaga Kereng Bangkirai. Adapun yang menjadi informan dalam wawancara ini adalah dari pihak pemerintah, swasta dan masyarakat.
a. Pihak Pemerintah : Dinas Kebudayaan dan Pariwisata Kota Palangka Raya
b. Pihak Swasta : Penyedia Jasa Di Seputar Wilayah Danau Kereng Bangkirai, Biro Perjalanan Wisata, dan Himpunan Pramuwisata Indonesia (HPI)
c. Pihak Masyarakat : Kelompok Sadar Wisata (POKDARWIS), Tokoh- tokoh Masyarakat dan Pengunjung Objek Wisata.

\section{Dokumentasi}

Metode Dokumentasi adalah suatu cara pengumpulan data yang menghasilkan catatan-catatan penting yang berhubungan dengan masalah yang diteliti, sehingga akan diperoleh data yang lengkap, sah dan bukan berdasarkan pemikiran Eddy dan Helmuth (2013:127). Dokumentasi adalah salah satu metode pengumpulan data berupa arsip, buku, dan gambar yang berhubungan dengan masalah penelitian. Dengan menggunakan dokumen sebagai data penelitian, tidak semua kondisi dan kejadian secara indrawi bisa terekam dan tersimpan dalam memori setiap orang.

Maka dari itu, dalam hal ini peneliti akan menggunakan dokumendokumen atau file-file dari instansi tertentu terutama Di Dinas Kebudayaan dan Pariwisata Kota Palangka Raya serta dokumentasi gambar saat peneliti melangsungkan wawancara dengan informan.

\section{TEKNIK ANALISIS DATA}

Menurut Miles dan Huberman (1992) dalam Sugiyono (2012:7), teknik analisa data kualitatif meliputi tiga alur kegiatan sebagai sesuatu yang terjalin pada saat sebelum, selama dan sesudah pengumpulan data dalam bentuk yang sejajar untuk membangun suatu analisis, yaitu reduksi data, penyajian data, dan penarikan kesimpulan.

Teknik analisa data yang digunakan dalam penelitian ini adalah analisa dengan menggunakan model interaktif (interactive models of analysis) yang dikembangkan oleh Miles dan Huberman (1992:16). Dalam model ini terdapat tiga komponen analisis, yaitu sebagai berikut :

\section{a. Reduksi Data}

Reduksi data diartikan sebagai proses pemilihan, pemusatan perhatian pada penyederhanaan, pengabstrakan dan transformasi data kasar yang muncul dari catatan tertulis di lapangan. Reduksi data merupakan suatu bentuk analisis yang menajamkan, menggolongkan, mengarahkan, membuang yang tidak perlu dan mengorganisasikan data dengan cara sedemikian rupa sehingga dapat ditarik kesimpulan atau verifikasi. Data yang diperoleh dari lokasi penelitian atau data lapangan ditulis dalam uraian yang jelas dan lengkap yang nantinya akan direduksi, dirangkum, dan difokuskan pada hal-hal yang 
berkaitan dengan penelitian kemudian dicari tema atau pola (melalui proses penyuntingan, pemberian kode, dan pembuatan tabel).

\section{b. Penyajian Data}

Penyajian data dilakukan dengan cara mendeskripsikan data yang ada secara sederhana, rinci, utuh, dan integrative yang digunakan sebagai pijakan untuk menentukan langkah berikutnya dalam menarik kesimpulan dari data yang ada. Dikarenakan penelitian ini juga penelitian kuantitatif maka penyajian data yang digunakan yaitu tabel distribusi frekuensi. Distribusi frekuensi adalah penyusunan suatu data mulai dari yang terkecil sampai yang terbesar yang membagi banyaknya data ke dalam beberapa kelas. Kegunaan data yang masuk dalam distribusi frekuensi adalah untuk memudahkan data dalam penyajian, mudah dipahami dan mudah dibaca sebagai bahan informasi, pada gilirannya digunakan untuk perhitungan membuat gambar statistik dalam berbagai bentuk penyajian data (Riduwan, 2009:66)

c. Penarikan Kesimpulan (Verifikasi)

Penarikan kesimpulan dilakukan secara terus menerus sepanjang proses penelitian berlangsung. Sejak awal memasuki lokasi penelitian dan selama proses pengumpulan data berlangsung, peneliti berusaha untuk menganalisis dan mencari makna dari data yang dikumpulkan, yaitu dengan mencari pola, tema, hubungan, persamaan dan hal-hal yang sering timbul yang dituangkan dalam kesimpulan yang tentative namun dengan bertambahnya data melalui verifikasi terus menerus akan memperoleh kesimpulan-kesimpulan yang bersifat grounded (dasar).

Proses analisis data secara interaktif dapat disajikan dalam bentuk skema sebagai berikut :

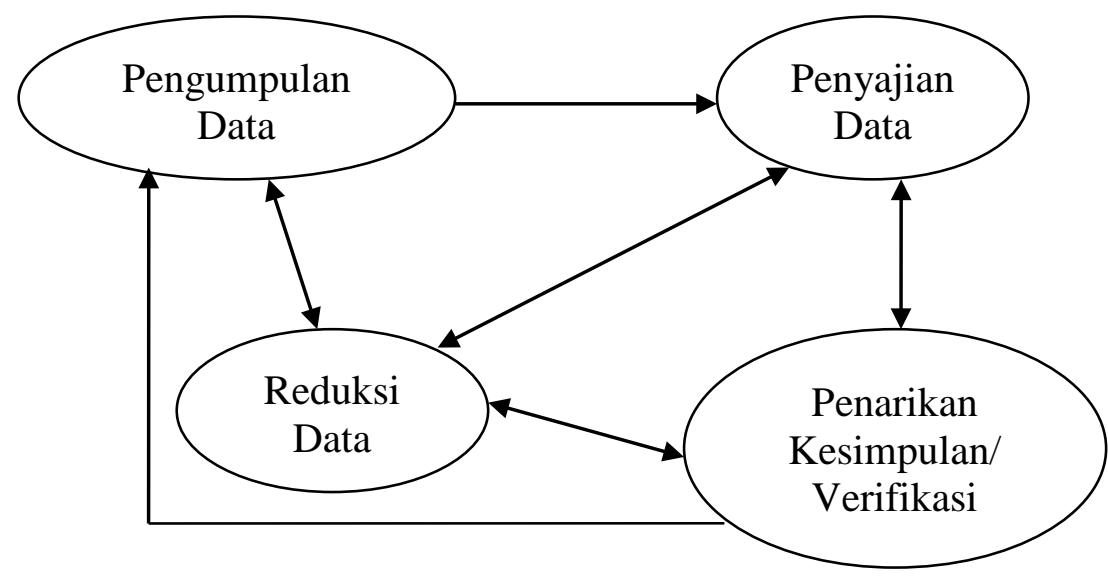

Gambar 3.1

Analisis Model Interaktif Menurut Miles dan Huberman Sumber : Miles dan Huberman (1992:20)

\section{PEMBAHASAN}

1. Kolaborasi yang dilakukan oleh Pemerintah, Swasta dan Masyarakat dalam melakukan Pembangunan Pariwisata 
Setiap organisasi pasti merancang dan melakukan upaya maupun strategi untuk mencapai tujuan organisasi tersebut. Begitu pula dengan Dinas Kebudayaan dan Pariwisata Kota Palangka Raya dalam melakukan Pembangunan Pariwisata di Kawasan Dermaga Kereng Bangkirai adalah dengan pihak swasta maupun masyarakat melalui :

\section{a. Komunikasi}

Komunikasi yang intensif sangatlah penting dalam kolaborasi. Kolaborasi dapat dilakukan secara langsung dan tidak langsung. Komunikasi yang dilakukan secara tidak langsung dapat melalui perantara teknologi. Komunikasi melalui perantara akan lebih efektif diterapkan pada kolaborasi yang terdapat konflik antar aktor.

Jika dilihat dari hasil penelitian di lapangan menunjukan bahwa Kolaborasi yang dilakukan oleh Pemerintah, Swasta dan Masyarakat dalam melakukan Pembangunan Pariwisata melalui komunikasi adalah dengan dibentuknya wadah serta saluran komunikasi yang bertujuan untuk saling memberikan manfaat antara lain dengan terbentuknya Pokdarwis juga pertemuan-pertemuan yang membahas tentang kepariwisataan, namun belum sepenuhnya memberikan kepuasan kepada masyarakat/swasta pada umumnya.

Jika dilihat dari hasil penelitian tersebut sesuai dengan pendapat yang dikemukakan oleh Robert Agranoff dan McGuire Michael (2003: 144-153) memandang kolaborasi sebagai aktivitas-aktivitas yang bersifat horizontal dan vertikal. Kemudian, aktivitas tersebut dianalisis melalui komunikasi, nilai tambah dan deliberasi. Untuk itu dapat dipahami bahwa komunikasi yang terlaksana antar pihak harus dilatarbelakangi oleh kepentingan dan tujuan yang sama yaitu membangun kawasan pariwisata Kereng Bangkirai. Namun demikian berdasar pada temuan lapangan masih terdapat hambatan komunikasi antar pihak.

\section{b. Nilai Tambah}

Nilai yang dimaksud disini adalah nilai publik, yakni yang dihasilkan dari efisiensi, demokrasi dalam institusi/organisasi, dan proses kolaborasi.

Jika dilihat dari hasil penelitian di lapangan menunjukan bahwa Kolaborasi yang dilakukan oleh Pemerintah, Swasta dan Masyarakat dalam melakukan Pembangunan Pariwisata yang menghasilkan nilai tambah adalah terjadinya keterlibatan semua unsur yang ada di wilayah Wisata Kereng Bangkirai baik pemerintah, swasta dan masyarakat. Namun demikian nilai tambah yang dimaksud belum dapat secara utuh digambarkan melalui ketersediaan data.

Jika dilihat dari hasil penelitian tersebut sesuai dengan pendapat yang dikemukakan oleh Robert Agranoff dan McGuire Michael (2003: 144-153) memandang kolaborasi sebagai aktivitas-aktivitas yang bersifat horizontal dan vertikal. Kemudian, aktivitas tersebut dianalisis melalui komunikasi, nilai tambah dan deliberasi. Untuk itu dapat dipahami bahwa adanya nilai ekonomi berupa munculnya sejumlah warung yang menjual berbagai macam makanan/minuman yang ada di kawasan dermaga Kereng Bangkirai.

\section{c. Deliberasi}


Deliberasi merupakan kelebihan dari kolaborasi yang membentuk pembelajaran saling menguntungkan (mutual learning), pembangunan komunitas (building communities), dan pemanfaatan proses interaktif (employing interactive).

Jika dilihat dari hasil penelitian di lapangan menunjukan bahwa Kolaborasi yang dilakukan oleh Pemerintah, Swasta dan Masyarakat dalam melakukan Pembangunan Pariwisata dapat menghasilkan deliberasi adalah terjadinya perubahan positif berupa menjamurnya tempat usaha berupa warung, toko, parkir dan penyediaan sewa perahu yang hampir seluruhnya merupakan inisiatif warga sekitar kawasan pariwisata Kereng Bangkirai. Ini menandakan adanya kondisi saling menguntungkan antara wisatawan, masyarakat dan lingkungan sekitar kawasan wisata.

Jika dilihat dari hasil penelitian tersebut sesuai dengan pendapat yang dikemukakan oleh Robert Agranoff dan McGuire Michael (2003: 144-153) memandang kolaborasi sebagai aktivitas-aktivitas yang bersifat horizontal dan vertikal. Kemudian, aktivitas tersebut dianalisis melalui komunikasi, nilai tambah dan deliberasi. Untuk itu dapat dipahami bahwa deliberasi adalah adanya kerjasama yang saling menguntungkan antara pihak pemerintah, swasta dan masyarakat Kereng Bagkirai.

\section{Faktor Pendukung dan Penghambat Kolaborasi yang dilaksanakan dalam Pembangunan Pariwisata}

Dinas Kebudayaan dan Pariwisata Kota Palangka Raya dalam melaksanakan pembangunan pariwisata di kawasan dermaga Kereng Bangkirai dipengaruhi oleh beberapa faktor, yaitu :

\section{a. Faktor Pendukung}

1) Ketersediaan sarana prasarana

Ketersediaan sarana prasarana merupakan modal pemerintah untuk merealisasikan suatu program. Sarana dan prasarana yang memadai lebih memudahkan pemerintah untuk mengimplementasikan program yang sudah direncanakan. Selain itu sarana prasarana juga bisa menjadi ukuran optimal atau tidaknya pemerintah untuk melaksanakan tugas dan fungsinya sebagai pelayan masyarakat.

2) Ketersediaan anggaran

Salah satu unsur penting dalam terselenggaranya suatu program atau kegiatan adalah anggaran. Anggaran menjadi faktor penunjang segala bentuk program pemerintah dalam menjalankan tugas dan fungsinya sebagai pelayan masyarakat. Besar kecilnya anggaran yang dimiliki tentu akan mempengaruhi efektivitas suatu program dan bisa menjadi kendala apabila anggaran yang dibutuhkan tidak sesuai.

3) Kemitraan

Kemitraan yang dijalin oleh Dinas Kebudayaan dan Pariwisata Kota Palangka Raya dalam melaksanakan pembangunan pariwisata adalah dengan pihak swasta maupun masyarakat. Sehingga 3 elemen penting dalam melaksanakan pembangunan pariwisata yaitu pemerintah, masyarakat dan swasta harus berjalan seiringan tanpa ada ketimpangan apapun. Agar tercipta sinergitas dan hubungan yang solid antar komponen dalam pengembangan dan pembangunan pariwisata di 
kawasan dermaga Kereng Bangkirai. Adapun bentuk kemitraan tersebut adalah Pokdarwis.

4) Peran serta masyarakat

Kiprah masyarakat sangat menentukan efektif atau tidaknya peran yang dijalankan oleh pemerintah. Kondisi masyarakat di suatu wilayah sangat berbeda, ada masyarakat yang kooperatif dan sangat mudah untuk diajak bekerjasama, namun ada pula masyarakat yang tidak kooperatif, apatis dan acuh terhadap segala program pemerintah. Masyarakat Kota Palangka Raya merupakan masyarakat yang memiliki tingkat pendidikan yang tinggi, memiliki nilai kebudayaan yang sangat kental dan cukup disiplin dalam berbagai hal. Masyarakat Kota Palangka Raya sangat mudah untuk diajak kerjasama dan cukup peduli terhadap kemajuan Kota Palangka Raya. Namun adakalanya akan terlihat tidak peduli apabila yang menjadi ajakan, himbauan dan larangan itu secara tidak langsung bersinggungan dengan kepentingannya. Sehingga Dinas Kebudayaan dan Pariwisata Kota Palangka Raya mengupayakan mengakomodasi seluruh kepentingan masyarakat yang berkaitan dengan kepariwisataan melalui paguyuban dan komunitas-komunitas yang ada antara lain adalah Kelompok Sadar Wisata agar saran, kritik, keluhan dan aspirasi dari setiap masyarakat Kota Palangka Raya melalui paguyuban bisa menjadi masukan dan kemudian bisa ditindak lanjuti oleh Dinas Kebudayaan dan Pariwisata Kota Palangka Raya.

\section{b. Faktor Penghambat}

1) Keterbatasan Sumber Daya Manusia

Dalam mengembangkan dan pembangunan pariwisata Dinas Kebudayaan dan Pariwisata Kota Palangka Raya terkendala oleh kuantitas serta kualitas sumber daya manusia yang tidak memadai. Kuantitas dan kualitas sumber daya manusia yang kurang memadai berakibat pada kurang optimalnya aktualisasi dari peran Dinas Kebudayaan dan Pariwisata Kota Palangka Raya untuk melakukan monitoring atau memberikan motivasi terhadap para pelaku wisata Kereng Bangkirai sehingga program hanya bersifat insidental. Selain itu kurang optimalnya juga aktualisasi peran untuk merangkul seluruh komponen untuk bersama-sama melakukan pengembangan dan pembangunan pariwisata di kawasan dermaga Kereng Bangkirai. Hal tersebut dapat terlihat bahwa belum adanya kegiatan koordinasi atau evaluasi bersama yang dilakukan oleh seluruh pemangku kepentingan Pariwisata.

2) Keterbatasan Anggaran

Ketersediaan anggaran pemerintah untuk mewujudkan pembangunan kepariwisataan relatif terbatas, mengingat begitu banyak peran pemerintah yang harus diwujudkan. Padahal anggaran merupakan hal yang penting untuk menentukan terselenggaranya program atau kegiatan. Tanpa adanya anggaran yang memadai maka program pun akan sulit dijalankan secara optimal. Begitu pula pengembangan dan pembangunan pariwisata di Kawasan Dermaga Kereng Bangkirai Kota Palangka Raya.

3) Kondisi Masyarakat yang Majemuk 
Hambatan yang dihadapi oleh Dinas Kebudayaan dan Pariwisata Kota Palangka Raya selain keterbatasan anggaran dan sumber Daya Manusia adalah kondisi masyarakat yang majemuk yang terdiri dari banyak masyarakat pendatang dari berbagai daerah di Indonesia. Hal tersebut menjadi tantangan dan permasalahan tersendiri bagi Dinas Kebudayaan dan Pariwisata Kota Palangka Raya untuk menjalankan peran dan fungsinya.

Kondisi masyarakat yang majemuk juga memberikan dampak akulturasi budaya lokal. Sehingga Peran Dinas Kebudayaan dan Pariwisata Kota Palangka Raya akan lebih sulit karena selain mempertahankan kebudayaan lokal yang ada, juga menata dan mengkomunikasikan segala sesuatunya terhadap masyarakat yang majemuk tersebut, mengingat budaya kepariwisataan belum sepenuhnya menjadi budaya yang melekat pada lingkungan masyarakat di wilayah Kereng Bangkirai. Sehingga masih terjadi pemahaman yang belum sepenuhnya memadai mengenai konsep sadar wisata. Untuk itu keberadaan Pokdarwis dapat memberikan kontribusi positif terhadap pemahaman masyarakat akan dunia kepariwisataan.

\section{KESIMPULAN}

Berdasarkan hasil penelitian dan pembahasan di atas maka dapat disimpulkan sebagai berikut:

1. Kolaborasi yang dilakukan oleh Pemerintah, Swasta dan Masyarakat dalam melakukan Pembangunan Pariwisata di Kawasan Dermaga Kereng Bangkirai

a. Komunikasi adalah dibentuknya wadah serta saluran komunikasi yang bertujuan untuk saling memberikan manfaat antara lain dengan terbentuknya Pokdarwis, juga pertemuan-pertemuan yang membahas tentang kepariwisataan, namun belum sepenuhnya memberikan kepuasan kepada masyarakat/swasta pada umumnya.

b. Nilai tambah adalah terjadinya keterlibatan semua unsur yang ada di wilayah wisata Kereng Bangkirai baik pemerintah, swasta dan masyarakat, maka terjalinnya proses kolaborasi dalam pembangunan pariwisata di dermaga Kereng Bangkirai. Masyarakat luas pada umum menyambut baik dengan adanya kehadiran tempat wisata yang ada di Kawasan wisata dermaga Kereng Bangkirai, hal ini dilihat dari bertambahnya minat wisatwan untuk berkunjung terutama pada akhir pekan/hari libur.

c. Deliberasi adalah adanya kerjasama yang saling menguntungkan antara pihak pemerintah, swasta dan masyrakat di kawasan dermaga Kereng Bangkirai, yang menghasilkan perubahan positif berupa menjamurnya tempat usaha berupa warung, toko, parkir dan penyediaan sewa perahu, sepeda bebek air, kapal susur sungai dan tempat berfoto yang hampir seluruhnya merupakan inisiatif warga sekitar kawasan pariwisata dermaga Kereng Bangkirai. Ini menandakan adanya kondisi saling menguntungkan antara wisatawan, masyarakat dan lingkungan sekitar kawasan wisata.

2. Faktor Pendukung dan Penghambat Kolaborasi yang dilaksanakan dalam Pembangunan Pariwisata di Kawasan Dermaga Kereng Bangkirai

a. Faktor Pendukung 
1) Pemerintah Yang menjadi faktor pendukung dalam pembangunan pariwisata adahah adanya ketersediaan sarana prasarana, ketersediaan anggaran, kemitraan, peran serta masyarakat.

2) Swasta Yang menjadi faktor pendukung dalam pembangunan pariwisata adahah adanya ketersediaan sarana prasarana, dan ketersediaan anggaran.

3) Masyarakat Yang menjadi faktor pendukung dalam pembangunan pariwisata adahah adanya ketersediaan sarana prasarana, dan penyediaan layanan/fasilitas wisata.

b. Faktor Penghambat

1) Pemerintah Yang menjadi faktor penghambat dalam pembangunan pariwisata adahah adanya keterbatasan sumber daya manusia, dan kondisi masyarakat yang majemuk.

2) Swasta

Yang menjadi faktor penghambat dalam pembangunan pariwisata adahah kurangnya kebijakan dari pemerintah Kota Palangka Raya dan Keterbatasan SDM masyarakat sekitar wisata.

3) Masyarakat

Yang menjadi faktor penghambat dalam pembangunan pariwisata adahah adanya keterbatasan sumber daya manusia dan keterbatasan anggaran.

\section{DAFTAR PUSTAKA}

\section{Sumber Buku:}

- Yoeti, Oka. 1990. Pengantar Ilmu Pariwisata, Edisi Revisi. Bandung: Angkasa.

- Abdul, Wahab. 2004. Analisis Kebijakan dari Formulasi ke Implementasi Kebijaksanaan Negara. Jakarta: Bumi Aksara.

- Agranoff, Robert dan Michael McGuire. 2003. Collaborative Public Management: New Strategies for Local Governments. Washington DC: Georgetown University Press.

- Akdon dan Riduwan, 2009. Aplikasi Statistika dan Metode Penelitian Untuk Administrasi dan Manajemen. Bandung: Dewa Ruci.

- Burkart A.J. dan S. Medlik. 1981. Tourism: Past, Present and Future. London: United Kingdom.

- Fandeli, Chafid. 1995. Dasar-Dasar Manajemen Kepariwisataan Alam. Yogyakarta: Liberty.

- Nawawi, Hadari. 2003. Manajemen Sumber Daya Manusia untuk Bisnis yang Kompetitif. Gadjah Mada University Press. Yogyakarta.

- Herdiansyah, Haris. 2011. Metodologi Penelitian Kualitatif. Jakarta: Salemba Humanika.

- Joyosuharto, Sunardi. 1995. Dasar-dasar Manajemen Kepariwisataan Alam. Yogyakarta: Liberty.

- Kodhyat. 1996. Sejarah Pariwisata dan Perkembangan di Indonesia. Bandung: Gramedia Widia Asarama Indonesia. 
- Lion, Eddy dan Helmuth Y. Bunu. 2013. Metodologi Penelitian Kualitatif. Surabaya: Jenggala Pustaka Utama.

- Mardikanto, Tatok dan Poerwoko Soebianto. 2013. Pemberdayaan Masyarakat Dalam Perspektif Kebijakan. Bandung: Alfabeta.

- Miles, B. Mathew dan Michael Huberman. 1992. Analisis Data Kualitatif Buku Sumber Tentang Metode-metode Baru. Jakarta: UIP.

- Moeljarto, Tjokrowinoto. 1987. Politik Pembangunan: Sebuah Analisis Konsep Arah dan Strategi. Yogyakarta: Tiara Wacana.

- Morris, John C. et al. 2015. Advancing Collaboration Theory: Models, Typologies, and Evidence. New York: Routledge.

- Musanef. 1996. Manajemen Usaha Pariwisata Di Indonesia. Jakarta: Toko Gunung Agung.

- Nazir, Moh. 2003. Metode Penelitian. Jakarta: Ghalia Indonesia.

- Patsy, Healey. 1996. Consesus-building Across Difficult Division: New Approaches to Collaborative Strategy Making.

- Pendit, Nyoman S. 1990. Ilmu Pariwisata Sebuah Pengantar Perdana. Jakarta: Pradnya Paramita.

- Rochajat, dkk. 1999. Ilmu Pariwisata. Jakarta: Akademi Pariwisata Trisakti.

- Rochajat, dkk. 2011. Komunikasi Pembangunan Perubahan Sosial, Perspektif Dominan, Kaji Ulang dan Teori Kritis. Jakarta: Rajagrafindo Persada.

- Rogers, E. M. 1985. Komunikasi dan Pembangunan, Perspektif Kritis. Jakarta: LP3ES.

Rostow, Walt.W. 1960. The Stages of Econimic Growth: a non-Communist Manifesto. London: Cambridge University Press.

- Soekadijo, R G. 1997. Anatomi Pariwisata: Memahami Pariwisata sebagai "Systemic Linkage”. Jakarta: Gramedia Pustaka Utama.

- Spillane J.J. 1987. Pariwisata Indonesia Sejarah dan Prospeknya. Yogyakarta: Kanisius.

- Subandi, Tjipto. 1994. Pariwisata Indonesia, Siasat Ekonomi dan Rekayasa Kebudayaan. Yogyakarta: Kanisius.

- Subandi, Tjipto. 2011. Inovasi Pendidikan. Surakarta: Universitas Muhammadiyah Surakarta.

- Sugiyono. 2012. Metode Penelitian Kuantitatif, Kualitatif, dan R\&D. Bandung: Alfabeta.

- Suwantoro, Gamal. 1997. Dasar-Dasar Pariwisata. Yogyakarta: Andi.

- Thomson, Ann Marie dan James L. Perry. 2006. Collaboration Processes: Inside the Black Box. Public Administration Review.

- Tjokrowinoto, Moeljarto, 1987. Politik Pembangunan, Sebuah Analisis Konsep, Arah, dan Strategi. Yogyakarta: Tiara Wacana

- Wrihatnolo, R.R, Dwijiwinoto R.N. 2007. Manajemen Pemberdayaan. Jakarta: Elek Media Komputindo.

\section{Sumber Perundang-Undangan :}

- Undang-Undang Republik Indonesia No. 10 Tahun 2009 tentang Kepariwisataan. 


\section{Sumber Jurnal :}

- Ansell, Chris, dan Alison Gash. 2007. Collaborative Governance in Theory and Practice. Journal of Public Administration Research and Theory.

- Rhama, Bhayu. 2017. The Implications Of The Values And Behaviours Of Actors For Ecotourism Policy: A Case Study Of Sebangau National Park, Central Kalimantan, Indonesia.

- Wood, Donna J. dan Barbara Gray. 1991. Towards a Comprehensive Theory of Collaboration. Journal of Applied Behavioral Science.

\section{Sumber Internet :}

- Heritage, American. https://ahdictionary.com/word/search.html?q= collaborate \&submit. $x=51 \&$ submit. $y=3$

- Merriam-Webster. Dictionary and Thesaurus. https://www.merriam webster.com/ dictionary/collaboration 